\section{Absorption and Translocation of Boron Applied to Aerial Tissues of Fruiting 'Reliance' Peach Trees}

\author{
Z.-H. Shu', G.H. Oberly, E.E. Cary ${ }^{2}$, and M. Rutzke \\ Department of Pomology, Cornell University, Ithaca, NY 14853 \\ Additional index words. Prunus persica, foliar spray, stable isotope enrichment
}

Abstract. Natural and ${ }^{10} B$-enriched boric acid solutions were sprayed on whole trees or certain parts of 'Reliance' peach trees (Prunus persica L. Batsch) to estimate the uptake and translocation of $B$. The tissues were analyzed for total $B$ and ${ }^{10} B:{ }^{11} B$ ratio. The single or multiple spray treatments of $233 \mathrm{mg} \mathrm{B/liter}$ applied at full bloom (FB), FB + 2 weeks, and $F B=4$ weeks did not increase $B$ concentrations in leaves or stems collected 45,75 , and 105 days following FB. Individual limbs sprayed with $0,200,400,600$, or $1200 \mathrm{mg} \mathrm{B} / \mathrm{liter}$ did not affect $B$ concentrations in six aerial plant parts harvested 3 days following treatment. Boron uptake and translocation were also studied by applying $30 \mu \mathrm{l}$ of $600 \mathrm{mg}$ $B /$ liter from ${ }^{10} B$-enriched boric acid as spot treatments to various peach plant parts. Leaves, stems, and fruit absorbed ${ }^{10} B$ and translocated it to nontreated tissues. However, only a small amount of ${ }^{10} B$ was absorbed by 3 days after treatment.

Boron deficiency in plants is the most widespread of the known essential micronutrient deficiencies and has been reported for one or more crops in 43 states of the United States (Sparr, 1970). The range of B concentrations between deficiency and toxicity levels can be relatively narrow for some plant species. Boron deficiency caused spring dieback of twigs and branches of peach trees that had grown normally the previous year (McLarty and Woodbridge, 1949). However, due to the sensitivity of different crops to $\mathrm{B}$, increasing the levels of $B$ available to some plants by even small amounts can cause B toxicity and reduce yield (Gupta, 1985). Boron toxicity in peaches induced by soil B application has been reported (Cibes et al., 1955). Since peach has been ranked sensitive to B (Ayers and Westcot, 1976), foliar B application to peaches is currently recommended in many growing areas of the world. Nevertheless, the basic knowledge of B uptake and translocation by peach trees and the factors influencing the uptake of foliar-applied B is limited (Swietlik and Faust, 1984 )

Received for publication 26 Apr. 1993. Accepted
for publication 5 Aug. 1993. We gratefully ac-
knowledge the donation of the ${ }^{10} \mathrm{~B}$-enriched boric
acid used in this study by Blue Eagle, Quapaw, Okla.
Mention of a trademark or proprietary product does
not constitute a guarantee or warranty of the product
by the U.S. Dept. of Agriculture or Cornell Univ.,
and does not imply its approval to the exclusion of
other products that may also be suitable. The cost of
publishing this paper was defrayed in part by the
payment of page charges. Under postal regulations,
this paper therefore must be hereby marked adver-
tisement solely to indicate this fact.
'Former Graduate Research Assistant, Dept. of Po-
mology, Cornell Univ. Currently, Associate Horti-
culturist, Dept. of Tropical Fruit Trees, Fengshan
Tropical Horticultural Experiment Station, TARI,
Fengshan, Kaohsiung 83017, Taiwan, Republic of
China.
${ }^{2}$ U.S. Plant, Soil and Nutrition Laboratory, Ithaca, NY 14853.
The objectives of this study were to determine whether $B$ applied to peach tree foliage is absorbed and translocated in adequate amounts to be an effective production practice.

\section{Materials and Methods}

Fruiting 6- to 8-year-old 'Reliance' peach trees at the LudlowvilleOrchard, Cornell Univ., were used in this study.

Boron uptake and growth stage. Three single-tree replications were sprayed until runoff with $233 \mathrm{mg} \mathrm{B} /$ liter of solution at 1) full bloom (FB) (25 Apr. 1986); 2) 2 weeks after FB; 3 ) 4 weeks after FB; 4) once at each of the times noted; and 5) water only at each of the above times (Expt. 1). Solubor $\left(\mathrm{Na}_{2} \mathrm{~B}_{\mathrm{d}} \mathrm{O}_{7} \cdot 5 \mathrm{H}_{2} \mathrm{O}\right.$ $+\mathrm{Na}_{2} \mathrm{~B}_{10} \mathrm{O}_{16} \cdot 10 \mathrm{H}_{2} \mathrm{O}$, containing $20.5 \%$ B; U.S. Borax \& Chemical Corp., Los Angeles) was the B source. Forty mature leaves from each tree were harvested from the middle position of the distal flushes (current-season's growth), and four defoliated stems of the current-season's growth were also harvested from the outer periphery of the trees. Both were harvested 45 (June), 75 (July), and 105 (August) days after the first spray.

Absorption and translocation. In Summer 1987, five 1-year-old branches of 10 to $12 \mathrm{~mm}$ basal diameter, similar vigor, and peripherally positioned were selected on each of three trees. Each branch had three or four fruit $\approx 2 \mathrm{~cm}$ long in growth Stage I, and the five branches on each tree were randomly assigned for treatment. One branch on each tree was sprayed on 18 May (FB + 21 days) with Solubor solutions of $0,200,400,600$, or $1200 \mathrm{mg} \mathrm{B} /$ liter at about pH 6.5 with $0.02 \%$ Charger-E (octylphenxypolyethoxy ethanol 80\%; Agway, Dewitt, N. Y.) surfactant (Expt. 2). Three days after treatment, the branches were removed and separated into terminal leaf, mid-shoot leaf, basal leaf, current-season shoot (defoliated), 1-year-old shoot (defoliated), and fruit.
A tracer study was conducted in Summer 1988 with ${ }^{10} \mathrm{~B}$-enriched boric acid that contained $94.7 \%{ }^{10} \mathrm{~B}\left({ }^{10} \mathrm{~B}:{ }^{11} \mathrm{~B}\right.$ ratio 17.86$)$ (Blue Eagle, Quapaw, Okla.) (Expt. 3). Twenty-one uniform trees were selected from a block of trees where neither soil nor foliar applications of B had been made. Seven branches of about the same size, growth angle in the tree, and vigor, and having a single fruit $\approx 6 \mathrm{~cm}$ long at growth Stage II were chosen for treatment on seven trees in each of three replications. ${ }^{10} \mathrm{~B}$ enriched boric acid solution was sprayed on an individual leaf located at the terminal, midshoot, and basal position of the shoot; and on the shoot-stem, fruit, or the entire shoot until runoff. The concentration of the ${ }^{10} \mathrm{~B}$-enriched boric acid solution was $600 \mathrm{mg} \mathrm{B} / \mathrm{liter}$ with $0.02 \%$ Charger-E surfactant and adjusted to $\mathrm{pH}$ 3. Exploratory experiments at $\mathrm{pH} 3$ indicated that absorption of B would be enhanced at this pH. Subsequent work indicated that B absorption was not differentially affected between $\mathrm{pH} 3$ or 6 (Shu, 1989). Before spraying ${ }^{10} \mathrm{~B}$ on the stem, we removed all but the termi

nal leaves. All treatments were made in plastic bags to minimize B contamination to adjacent tissues. The bags were removed after all runoff had ceased and the excess spray was contained. The branches were removed at the point of origin and sectioned for analysis after 3 days.

Sample analysis and data processing. All samples were washed twice with deionized water, oven-dried at $65 \mathrm{C}$ for $72 \mathrm{~h}$, ground, and stored in B-free containers until analyzed. A 400-mg sample was dry-ashed in a quartz tube at $450 \mathrm{C}$ for $6 \mathrm{~h}$. The ashed sample was cooled, and $0.25 \mathrm{ml}$ of $30 \% \mathrm{H}_{2} \mathrm{O}_{2}$ was added before reashing at $450 \mathrm{C}$ for $2 \mathrm{~h}$. The ash was dissolved in $0.5 \mathrm{ml}$ of $37 \% \mathrm{HC} 1$. After $1 \mathrm{~h}$, the dissolved sample was diluted with sufficient force to mix the sample with $9.5 \mathrm{ml}$ of distilled water containing $4.0 \mathrm{Kg}$ of yttrium (Y), an internal standard. Total B was determined using an inductively coupled argon plasma atomic emission spectrometer (ICP-AES) (model 957; Jarrel-Ash, Franklin, Mass.) and an inductively coupled argon plasma mass spectrometer (ICP-MS) (Elan model 250; SCIEX, Thornhill, Ont., Canada) for the ${ }^{10} \mathrm{~B}:{ }^{11} \mathrm{~B}$ ratio.

After the concentration of total $\mathrm{B}$ and ${ }^{10} \mathrm{~B}$ : ${ }^{11} \mathrm{~B}$ ratio were obtained, microgram of ${ }^{10} \mathrm{~B}$ was computed. Total $\mathrm{B}$ and ${ }^{10} \mathrm{~B}$ content of each plant part in this study were the total amount in the relevant plant parts, e.g., the value for the terminal leaf is the sum of six terminal leaves, one leaf from each of six shoots.

\section{Results}

Boron concentrations in leaves and stems were not affected by Solubor sprays of $233 \mathrm{mg}$ B/liter applied at FB, FB +2 weeks, $\mathrm{FB}+4$ weeks, or once at each of the preceding dates (1986 data not shown). Leaves had a higher B concentration $\left(\approx 30 \mathrm{mg} \cdot \mathrm{g}^{-1}\right)$ than the shootstems $\left(\approx 16 \mathrm{mg} \cdot \mathrm{g}^{-1}\right)$. Boron concentrations in the leaf and stem tissues decreased as the sampling dates from FB increased (data not shown).

Absorption and translocation. The termi- 
nal leaf had the highest $\mathrm{B}$ concentration and the 1-year-old shoot-stem had the lowest among all the plant parts analyzed. There was no significant difference in $\mathrm{B}$ concentration in the same plant part due to spray applications of B at $0,200,400,600$, or $1200 \mathrm{mg} \cdot \operatorname{liter}^{-1}(1987)$.

Plant parts treated with ${ }^{10} \mathrm{~B}$ (1988) had higher ${ }^{10} \mathrm{~B}$ contents than nontreated parts (Table la). With few exceptions, the ${ }^{10} \mathrm{~B}$ content in the plant parts was highest when the whole shoot was sprayed. However, absorption of ${ }^{10} \mathrm{~B}$ was greatest when it was applied directly to the fruit, where $\approx 90 \%$ remained (Table la).

When the whole shoot was sprayed, terminal leaves, mid-shoot leaves, and" fruit each had $\approx 25 \%$ of the total ${ }^{10} \mathrm{~B}$ recovered, while shoot-stem had $\approx 1 \%$ (Table $\mathrm{lb}$ ). When terminal leaves were sprayed, about half of the absorbed ${ }^{10} \mathrm{~B}$ remained in the leaves and onethird was translocated to the fruits. Mid-shoot leaves of the mid-shoot spray treatment contained about half, the fruit about one-fourth, and the terminal leaves about one-tenth of the absorbed ${ }^{10} \mathrm{~B}$. There was a small percentage ( $1 \%$ to $2 \%$ ) of ${ }^{10} \mathrm{~B}$ found in the terminal and mid-shoot leaves of the basal-leaf treatment. About two-thirds of the absorbed ${ }^{10} \mathrm{~B}$ stayed in the basal leaves, with about one-fourth being transported to the fruit.

More than $94 \%$ of the absorbed ${ }^{10} \mathrm{~B}$ was translocated to the terminal leaves when stems were sprayed. The stem contained $<5 \%$ of the total ${ }^{10} \mathrm{~B}$; however, the absolute amount was higher in comparison to nontreated stems. When ${ }^{10} \mathrm{~B}$ was applied to the fruit, $\approx 90 \%$ of the ${ }^{10} \mathrm{~B}$ absorbed stayed in the treated fruit. Never-

theless, ${ }^{10} \mathrm{~B}$ enrichment was noted in all other plant parts. The highest accumulation of ${ }^{10} \mathrm{~B}$ was in the mid-shoot leaves, followed by the basal and terminal leaves, and the least was found in the stem tissue. In the three treatments where leaves were sprayed, the highest percentage of the exported ${ }^{10} \mathrm{~B}$ moved to the fruit, while the stem received the least ${ }^{10} \mathrm{~B}$ in all six treatments. The total B found in control tissue was generally similar to that found in the treated tissue (Table lc).

\section{Discussion}

Peach absorbed much less B than did 'Italian' prune (Prunus domestics L.) (Hanson et al., 1985). Boron concentration in treated prune leaves increased 3 -fold in just $24 \mathrm{~h}$, while treated peach leaves showed little or no increase (Table $1 \mathrm{c}$ ). However, similar to 'Italian' prune, the foliar-applied B was quite mobile in peach trees. The B concentration in treated prune leaves decreased rapidly from $150 \mathrm{mg} \cdot \mathrm{kg}^{-1}$ to $<50 \mathrm{mg} \cdot \mathrm{kg}^{-1}$ in 30 days. For peach trees, from $\approx 10 \%$ (fruit) to $\approx 95 \%$ (shootstem) of the absorbed ${ }^{10} \mathrm{~B}$ was exported from the treated tissue to the nontreated plant parts in 3 days (Table $1 b$ ).

There was a contrast between the two treatment categories. Tissues from growth stage and $\mathrm{B}$ rate treatments using Solubor and harvested 3 days after spraying showed no significant $\mathrm{B}$ absorption. These results are similar to the lack of $\mathrm{N}$ response to foliar urea or $\mathrm{KNO}_{3}$ spray applications on peaches (Dilley and

Table 1. Absorption and translocation of $0.6 \mathrm{~g} \mathrm{~B} /$ iter of ${ }^{10} \mathrm{~B}$-enriched boric acid applied to various plant parts.

\begin{tabular}{|c|c|c|c|c|c|c|c|}
\hline \multirow[b]{3}{*}{$\begin{array}{l}\text { Tissue } \\
\text { Sampled }\end{array}$} & \multicolumn{7}{|c|}{ Tissue sprayed treatment } \\
\hline & & & & Leaf & & & \\
\hline & Control & $\begin{array}{l}\text { Whole } \\
\text { shoot }\end{array}$ & Terminal & $\begin{array}{l}\text { Mid- } \\
\text { shoot }\end{array}$ & Basal & $\begin{array}{c}\text { Shoot- } \\
\text { stem }\end{array}$ & Fruit \\
\hline
\end{tabular}

\begin{tabular}{|c|c|c|c|c|c|c|c|}
\hline \multirow{2}{*}{\multicolumn{8}{|c|}{ Leaf }} \\
\hline & & & & & & & \\
\hline Terminal & $0.0 \mathrm{~b}^{2}$ & $38.9 \mathrm{~b}$ & $27.2 \mathrm{~b}$ & $2.5 \mathrm{~b}$ & $0.8 \mathrm{~b}$ & $122.7 \mathrm{a}$ & $4.0 \mathrm{~b}$ \\
\hline Mid-shoot & $0.0 \mathrm{~b}$ & $40.5 \mathrm{a}$ & $4.0 \mathrm{~b}$ & $12.7 \mathrm{~b}$ & $0.7 \mathrm{~b}$ & $---y$ & $5.7 \mathrm{~b}$ \\
\hline Basal & $0.0 \mathrm{a}$ & $29.1 \mathrm{a}$ & $8.1 \mathrm{a}$ & $1.1 \mathrm{a}$ & $24.2 \mathrm{a}$ & $---^{y}$ & $5.5 \mathrm{a}$ \\
\hline Shoot-stem & $0.0 \mathrm{~b}$ & $1.7 \mathrm{~b}$ & $0.7 \mathrm{~b}$ & $0.6 \mathrm{~b}$ & $0.7 \mathrm{~b}$ & $6.4 \mathrm{a}$ & $1.1 \mathrm{~b}$ \\
\hline Fruit & $0.0 \mathrm{~b}$ & $38.3 \mathrm{~b}$ & $17.4 \mathrm{~b}$ & $6.7 \mathrm{~b}$ & $9.8 \mathrm{~b}$ & $1.2 \mathrm{~b}$ & $141.7 \mathrm{a}$ \\
\hline Sum ${ }^{10} B$ & $0.0 \mathrm{c}$ & $148.5 \mathrm{a}$ & $67.4 \mathrm{a}-\mathrm{c}$ & $23.6 \mathrm{bc}$ & $36.1 \mathrm{bc}$ & $130.3 \mathrm{ab}$ & $158.0 \mathrm{a}$ \\
\hline \multicolumn{3}{|c|}{ Percent ${ }^{10} \mathrm{~B}$ exported ${ }^{\mathrm{x}}$} & 59.6 & 46.2 & 33.1 & 95.1 & 10.3 \\
\hline \multirow{2}{*}{\multicolumn{8}{|c|}{ (b) ${ }^{10} B$ recovered $(\%)^{w}$}} \\
\hline & & & & & & & \\
\hline Terminal & --- & 26.2 & 52.5 & 10.6 & 2.2 & 94.2 & 2.6 \\
\hline Mid-shoot & --- & 27.3 & .7 .7 & 53.8 & 1.9 & $--^{y}$ & 3.7 \\
\hline Basal & --- & 19.6 & 4.8 & 4.7 & 67.0 & $\ldots y$ & 3.6 \\
\hline Shoot-stem & --- & 1.1 & 1.4 & 2.5 & 1.9 & 4.9 & 0.7 \\
\hline Fruit & --- & 25.8 & 33.6 & 28.4 & 27.0 & 0.9 & 89.3 \\
\hline \multirow{2}{*}{\multicolumn{8}{|c|}{ (c) Total B $\left(m g \cdot k^{-1}\right)$}} \\
\hline & & & & & & & \\
\hline Terminal & $56.6 \mathrm{~b}$ & $72.4 \mathrm{~b}$ & $67.5 \mathrm{~b}$ & $55.2 \mathrm{~b}$ & $57.2 \mathrm{~b}$ & $175.5 \mathrm{a}$ & $64.7 \mathrm{~b}$ \\
\hline Mid-shoot & $61.0 \mathrm{~b}$ & $81.1 \mathrm{a}$ & $62.8 \mathrm{~b}$ & $68.6 \mathrm{ab}$ & $61.1 \mathrm{~b}$ & $\ldots y$ & $70.7 \mathrm{ab}$ \\
\hline Basal & $67.3 \mathrm{ab}$ & $76.5 \mathrm{a}$ & $56.1 \mathrm{~b}$ & $64.7 \mathrm{ab}$ & $72.2 \mathrm{ab}$ &.$--y$ & $62.8 \mathrm{ab}$ \\
\hline Shoot-stem & $20.6 \mathrm{c}$ & $27.0 \mathrm{bc}$ & $19.9 \mathrm{c}$ & $40.4 \mathrm{a}$ & $27.6 \mathrm{bc}$ & $34.2 \mathrm{ab}$ & $27.9 \mathrm{bc}$ \\
\hline Fruit & $54.3 \mathrm{~b}$ & $55.0 \mathrm{~b}$ & $48.6 \mathrm{~b}$ & $54.4 \mathrm{~b}$ & $61.1 \mathrm{~b}$ & $50.5 \mathrm{~b}$ & $81.9 \mathrm{a}$ \\
\hline
\end{tabular}

${ }^{2}$ Mean separation within rows by Duncan's multiple range test, $P \leq 0.05$.

${ }^{y} \mathrm{Mid}$-shoot and basal leaves removed before application.

${ }^{\times}$Percent exported of the total ${ }^{10} \mathrm{~B}$ absorbed by the sprayed tissue, calculated from (total sprayed tissue)/total $\times 100 \%$.

${ }^{\mathrm{w}} \mathrm{Calculated}$ from $\left({ }^{10} \mathrm{~B}\right.$ enrichment in the plant part $) /$ total ${ }^{10} \mathrm{~B} \times 100 \%$.

Walker, $1961 \mathrm{a}, 196$ lb; Leece and Kenworthy, 197 1). In contrast, with ${ }^{10} \mathrm{~B}$-enriched boric acid and harvest also 3 days after the spray (Table 1), there was applied ${ }^{10} \mathrm{~B}$ uptake.

Boron has been classified as either immobile or mobile in plant tissues depending on the researchers. Neales ( 1960) found that the bean (Phaseolus vulgaris L.) radicle ceased to grow very quickly when deprived of B. Boron accumulates in the old leaves of plants and generally stays there even when B deficiency occurs in the root or shoot apex (Brown and Jones, 197 1). In contrast, normal new growth of broccoli (Brassica oleracea L. Botrytis Group) (Benson et al., 1961) and grape (Vitis vinifera L.) (Scott and Schrader, 1947) was found to continue for some time at the expense of the $\mathrm{B}$ in mature leaves when no external B was applied. Shelp (1988), after determining the composition of phloem exudates in broccoli, suggested that B was phloem mobile. Furthermore, Charnel et al. (1981), also using ${ }^{10} \mathrm{~B}$ as a tracer, found that $24 \mathrm{~h}$ after foliar B application to radish (Ruphanus sativus $\mathrm{L}$.), the absorbed $\mathrm{B}$ had migrated to the epicotyl and hypocotyl. The results of the present study confirm that $B$ is mobile for peaches (Table 1). Two reasons for differences between the two theories, i.e., immobile vs. mobile, may be 1) the amount of $\mathrm{B}$ uptake through peach plant parts is small (estimated $<0.5 \%$ ) and it would be rapidly diluted by growth; 2 ) since the translocation of the absorbed $\mathrm{B}$ in the nontreated plant parts happens rapidly (within 3 days, Table 1), the absorbed B would be redistributed throughout the plant in a short period and subsequently difficult to measure. Consequently, even though a plant part had a relatively high B uptake, the B concentration in the plant part harvested 1 week or more after treatment would decrease to about the same concentration as before the application(s), as found in Expts. 1 and 2. Thus, it would be difficult to detect B uptake and/or absorption when using natural B .

Leaves from the mid-shoot and basal-leaf spray treatments contained only $\approx 46 \%$ and $70 \%$ as much ${ }^{10} \mathrm{~B}$ as that of leaves from the terminal-leaf spray treatment (Table 1a). This finding is similar to results reported by Bukovac et al. (1979) for 'Redhaven' peach leaves. They found the aqueous solution retention ability decreased with leaf expansion. Rutland and Bukovac (1968) also indicated that the rates of foliar absorption generally decreased with increasing leaf age. However, the greater absorption of ${ }^{10} \mathrm{~B}$ by the mid-shoot leaf in this study is unexplained. The fact that most of the absorbed ${ }^{10} \mathrm{~B}$ (i.e., $67 \%$ ) for the basal-leaf spray treatment remained in the treated leaves probably indicates that basal leaves were less capable of translocating the absorbed ${ }^{10} \mathrm{~B}$. This probability is supported by the limited amount of ${ }^{10} \mathrm{~B}$ that was absorbed by the basal leaves and then transported to the younger leaves, as compared to that being transported after terminal and mid-shoot leaf treatments. However, $27 \%$ of the absorbed ${ }^{10} \mathrm{~B}$ for the basal-leaf treatment was translocated into the fruit.

The relatively high ${ }^{10} \mathrm{~B}$ content in the terminal leaf when shoot and stem were sprayed probably resulted from absorption of the $\mathrm{B}$ in the spray solution into the xylem system through the open cuts of the leaf petioles after 
the leaves were detached. In 3 days, $\approx 94 \%$ of the absorbed ${ }^{10} \mathrm{~B}$ reached the terminal leaves. Peach shoot-stems and fruit apparently were capable of absorbing more of the applied ${ }^{10} \mathrm{~B}$ than the leaves (Table la). We assume that the greater B absorption of the shoot-stem was through the cut leaf petioles; however, total absorbing areas of these tissues were not calculated. Fruit was the plant part that showed relatively high absorption and translocation ability.

To summarize, the aerial plant parts of peach trees were capable of absorbing and translocating B that was supplied through foliar application. However, the total amount of $\mathrm{B}$ absorbed was small, with the fruit being the primary sink. It received the largest percentage of the exported ${ }^{10} \mathrm{~B}$ from the other treated plant parts. Terminal leaves were the second largest sink and the shoot-stem the smallest, receiving no more than $2.5 \%$ of the total translocated ${ }^{10} \mathrm{~B}$.

\section{Literature Cited}

Ayers, R.S. and D.W. Westcot. 1976. Water quality for irrigation. Irrigation and drainage paper 29, Food and Agriculture Organization of the United Nations, Rome.
Benson, N. R., E.S. Degmann, and I.C. Chmelir. 1961. Translocation and reuse of boron in broccoli. Plant Physiol. 36:296-301.

Brown, J.C. and W.E. Jones. 1971. Differential transport of boron in tomato (Lycopersicon esculentum). Physiol. Plant. 25 :279-282.

Bukovac, M.J., J.A. Flore, and E.A. Baker. 1979. Peach leaf surfaces: Changes in nettability, retention, cuticular permeability, and epicuticula wax chemistry during expansion with special reference to spray application. J. Amer. Soc. Hort. Sci. 104:61 1-617.

Charnel, A., A.-M. AndrÄani, and J.-F. Eloy. 1981 Distribution of foliar-applied boron measured by spark source mass spectrometry and laser probe mass spectrography. Plant Physiol. 67:457-459.

Cibes, H. R., E. Hernandez, and N.F. Childers. 1955 Boron toxicity induced in a New Jersey peach orchard. Part I. Proc. Amer. Soc. Hort. Sci. 66:13-20.

Dilley, D.R. and D.R. Walker. 1961a. Urease activity of peach and apple leaves. Proc. Amer. Soc. Hort. Sci. 77:121-134.

Dilley, D.R. and D.R. Walker. 1961b. Assimilation of $14 \mathrm{C}, 15 \mathrm{~N}$ labeled urea by excised apple and peach leaves. Plant Physiol. 36:757-761.

Gupta, U.C. 1985. Boron toxicity and deficiency: A review. Can. J. Soil Sci. 65:381409.

Hanson, E.J., M.H. Chaplin, and P.J. Breen. 1985. Movement of foliar applied boron out of leaves and accumulation in flower buds and flower parts of 'Italian' prune. HortScience 20:747748.

Leece, D.R. and A.L. Kenworthy. 1971. Effect of potassium nitrate foliar sprays on leaf nitrogen content and growth of peach trees. HortScience 6:171-173.

McLarty, H.R. and C.G. Woodbridge. 1949. B in relation to"the culture of the peach. Phytopathology 39:86-861.

Neales, T.F. 1960. Some effects of boron on root growth. Austral. J. Biol. Sci. 13:232-248.

Rutland, R.B. and M.J. Bukovac. 1968. Foliar absorption of iron by chrysanthemum as influenced by lime induced chlorosis. Proc. Amer. Soc. Hort. Sci. 93:569-575.

Scott, L.E. and A.L. Schrader. 1947. Effect of alternating conditions of boron nutrition upon growth and boron content of grapevines in sand culture. Plant Physiol. 22:526-537.

Shelp, B.J. 1988, Boron mobility and nutrition in broccoli (Brassica oleracea var. Italica). Ann. Bet. $61: 83-91$.

Shu, Z.-H. 1989. Aerial absorption and translocation of boron in peach trees. PhD diss., Cornell Univ., Ithaca, N.Y.

Sparr, M.C, 1970. Micronrrtrient needs-which, where, on what-in the United States. Soil Sci. Plant Anal. 1 :241-262.

Swietlik, D. and M. Faust. 1984. Foliar nutrition of fruit crops. Hort. Rev. 6:287-357. 